\author{
Jaro Veselinovič, (Slovenija) \\ Department of Ethnology and Cultural Anthropology \\ The Faculty of Arts \\ The University of Ljubljana \\ e-mail: jaro.veselinovic@gmail.com
}

\title{
WAITING AND HOPING IN POSTSOCIALIST MACEDONIA: BETWEEN YUGOSLAV SOCIALISM AND THE EUROPEAN UNION
}

\begin{abstract}
The text deals with the changes in Macedonian society after the fall of Yugoslav socialism and the creation of a new independent Republic of Macedonia. The text also shows how Macedonian citizens project their future in a country that has been mired in geopolitical uncertainty for the last thirty years, which was crucial for shaping the past and future development of the country.
\end{abstract}

Keywords: Yugoslavia, Macedonia, socialism, post-socialism, European Union

This article explores changes in Macedonian society since the fall of Yugoslav socialism and the establishment of the newly independent Republic of Macedonia. At the same time, it tries to show how Macedonian citizens are projecting their future(s) in a country that was entrapped in geopolitical limbo for the last thirty years that decisively shaped the past and future development of the state.

During my almost one-year-long stay in the Republic of Macedonia, omnipresent debates around the political and economic state of affairs in the country sparked my interest in the course of transformation of everyday life in the last thirty years of its independence. Through the interviews I conducted, some of the officials, others less, I realized that two main aspects extensively characterized the postsocialist experience of Macedonian citizens, namely waiting and hoping. Most of my ethnographic fieldwork took place in Kriva Palanka in May of 2019. In addition, however, I participated in numerous muabets that gave me a glimpse into Macedonian everyday way of life during trips throughout the country in the months before.

The article is divided into five main parts, starting with a brief history of Macedonian political relations with Greece that greatly influenced the development of post-1991 Macedonia. Therefore, crucial to understand the Macedonian situation today. The second part briefly describes the process of privatization in the country with particular emphasis on Kriva Palanka; the third part is dedicated to the notion above of waiting, while the last two parts, the fourth and fifth parts are dealing with hope and future as imagined by my interlocutors in the town of Kriva Palanka.

During the last decades, in an ethnological and anthropological context, Macedonia and Macedonians were mostly subjects in researches that dealt with questions regar- 
ding their (national) identity (see, for example, Danforth 1995; Filak 2016; Jezernik 2002; Karakasidou 1997; Poulton 2000; Risteski and Hysa 2014; Schwartz 1996). Meanwhile, social, economic, and political aspects of everyday life in postsocialist Macedonia were some exceptions (see, for example, Monova 2014, 2015a, 2015b; Neofotistos 2012; Ramet 2017; Thiessen 1999), were to some extent neglected. This needs to be understood in Macedonian history and relations with its neighboring countries, especially Greece and, to a later time, Bulgaria. One of the most topical issues was its name after it seceded from the Socialist Federative Republic of Yugoslavia. According to Greek nationalist discourse regarding the Macedonian question, ancient Macedonians were Greeks. Therefore, they can't conceive that somebody else than ethnic Greeks could call themselves Macedonians and live in a country that is named the same as the historical region of Macedonia. Greek nationalist discourse imagines a strong line of continuity with Ancient Greece, mainly through linguistic and territorial perspective - modern Greek language evolved from ancient Greek, and most of the ancient Greek polis were located on the territory of present-day Greece (Fidanovski 2018: 20). Modern Macedonian state is therefore perceived as an artificial creation, „an ,invention, of Tito, who ,baptized“ a ,mosaic of nationalities“ with the Greek name ,Macedonia“ for his political purposes“ (Danforth 2010: 576), inhabited by descendants of Slavic tribes that settled in the area in the 6th century A.D. and therefore have no links whatsoever to Alexander the Great, a figure that plays a prominent role in present-day Macedonian nationalist imagination.

Macedonian side, on the other hand, found itself in an unenviable position. As a newly established country that, before 1944, did not have a self-governing entity on its territory was at the same time facing prospects of the difficult economic and political transition period following the dissolution of Yugoslavia as well as pressure from powerful neighbors (especially Greece but also Bulgaria) regarding its national symbols and name of the country. Besides the name, the official flag of the Republic of Macedonia was also a hot-button issue since Macedonians decided that the sixteen pointed star of Kutlesh as known as Sun of Vergina, should be depicted on the country's flag. This, however, was unacceptable for Greeks who see the Sun of Vergina as an identification symbol of Greeks (linking it directly to Phillip II, father of Alexander the Great) and could therefore not be used as a national symbol of another country (see Nedelkov 2011: 43). After the disownment of the flag, the saga concerning the name has begun. Although the Republic of Macedonia has amended its constitution to include an explicit pledge of no territorial claims to the rest of the historical region of Macedonia, Greece's position on Macedonia's global integration remained unchanged (Fidanovski 2018: 19). This in practice meant that Macedonian global integration was hindered - immediate international in 1991 recognition was halted due to Greek objections while in the following year European Community issued a declaration stating that it is willing to recognize that republic within its existing borders but with a name that does not include the term Macedonia. Recognition from E.U. states came in 1994 after Macedonia's admittance to the U.N. under the provisional name of „former Yugoslav Republic of Macedonia“ that was to be used only until the dispute was resolved (Daskalovski 2011: 58).

The dispute did come to an end with the so-called Prespa Agreement that was signed June 17th, 2018, and which predicted that the new name of the country should be the Republic of North Macedonia. The confirmation of the agreement was met with relative- 
ly public solid dissatisfaction and opposition on the Macedonian and the Greek side, followed by mass protests in Skopje and Thessaloniki. Macedonian PM Zoran Zaev decided that the only way to confirm the agreement conclusively was to call for a referendum in autumn where citizens would decide further development. For the referendum to be successful, at least $50 \%$ of voters had to cast their votes, and the majority had to favor the name change. Since the opposition's stance on the referendum was to boycott it, only 37\% of voters came to the polling stations, and an overwhelming majority of the - $94 \%$ - voted „yes." Although 50\% margin was not met, meaning the referendum was not valid, Zaev decided that will of people was manifested enough and pushed for constitutional changes that required two-thirds of the votes of the 120-seat Macedonian parliament, a majority that Zaev, together with votes from members of the opposition, managed to secure on October 15th, 2018. The name of the country officially changed in February 2019, and this opened space for progress in Macedonia's international aspirations, especially integration into European Union and NATO.

The described conflict is just one of the aspects that characterize the situation in which Macedonia and Macedonians found themselves years after their independence. That was among my interlocutors broadly referred to as chaos. Chaos marks a whole array of feelings related to changes that occurred after 1991 in one's personal life in terms of unemployment, growing emigration of family members, loss of social networ$\mathrm{k}(\mathrm{s})$ as well as to changes related to the broader socio-political situation that is characterized by unpredictability, increasing nationalism and widespread corruption and clientelism. These aspects of everyday life in the country were brought up in everyday conversations and interviews during my fieldwork in Kriva Palanka, a middle-sized Macedonian city in the very north-eastern part of the country. Stretched along Kriva Reka (meaning curved river) and Duračka Reka, with the main road connecting Skopje and Sofia passing through the city, Kriva Palanka used to be an important strategic location during the centuries of its existence. The town itself is divided into an older part consisting of old Turkish čaršija and a new part of the city, built during the Kingdom of Yugoslavia and later SFRY. During the latter period, SFRY, Kriva Palanka witnessed the most significant progress in terms of economy and industrialization as well as overall everyday life standard. One of the most important factories in the city was the textile plant „Karpoš“ that at its peak employed as many as 1680 workers (Malkovski, Mihajlovski in Krstevski 1996: 246), while other important industrial enterprises were „Toranica“ mine, wood factory „Osogovo“ and construction companies „Ruen“ and „Bentomak.“

All of the companies mentioned above decayed in the first years of the "transition" that followed the fall of the Yugoslav socialist system. One of the reasons was the process of privatization that started immediately after Macedonian independence. One of my interlocutors, a local historian Joakim from Kriva Palanka, briefly described how privatization in the country happened:

Transition is, in its essence, a transformation of public capital into a private one. Macedonia did, in 1991, change its socio-economical model and started following market-oriented policies based on neoliberal logic. There are many ways in which transformation can be carried out; however, all of them were used in Macedonia. The most widespread strate- 
gy was to buy company shares, so-called certificates, from workers, so that majority of a particular company or factory ended up in the hands of private owners that had neither means nor intention actually to develop these companies further. Furthermore, many companies were intentionally devaluated to get sold, in some cases up to $60 \%$ of their actual value.

This in practice meant that many factories were sold for less than what they were worth, often to local "tycoons" that later on deliberately financially exhausted companies and put workers out of their jobs. Moreover, as Jelena Džankić points out, privatization in certain post-Yugoslav countries took place in a relatively lawless environment that enabled an uncontrolled transfer of public property into private hands that often belonged to those who held political power in socialism and therefore ensured continuity of power for themselves through control of economic means of production (Džankić 2018: 89).

The certificates mentioned above or company shares are given to factory workers were meant to ensure a fair and transparent distribution of what was once public property. But in practice, as Sabrina Ramet points out, many of the workers were forced into selling them or were, due to lack of knowledge of what certificates mean, even giving them for free to local politicians and members of the newly established entrepreneur class (2017: 296). Joakim described the situation in Kriva Palanka during the 1990s:

Look, they promised workers that they would get... The workers got certificates later bought by essential persons from the municipality or speculators with a promise that they would still be able to work in factories, which was not valid. And what is the most perverted thing is that from 1997 until today, not even one political party gave any official statement or declaration about the end of the Macedonian transition. It was left undefined; it is still not clear whether this process finished. But it is possible to conclude that quick and full-scale privatization was the only way to disable any kind of mass mobilization or revolt that would change its course. Workers were thrown on the streets. Their existence is even today endangered. It is no wonder that we are witnessing a constant growth in unemployment and emigration after all these decades.

This, in turn, meant that many individuals and a whole society found themselves in a completely new situation that now lasts for as many as 30 years. Although Macedonia peacefully succeeded from SFRY and was therefore not subjected to any direct war-related consequences, its development, particularly the international one, was somewhat halted due to blockades from Greece. These 30 years were and, according to conversations I had, still are, characterized by two widespread sentiments that strongly influence how Macedonians comprehend their situation today - waiting and hoping.

Waiting is, in a way, one of the most common activities in Macedonia, both personally or in terms of everyday conversations with friends and acquaintances. For example, one can spend hours waiting for a residence permit in a substantial black building next to Vardar river in Skopje city center where the seat of the Macedonian Interior ministry is and where, no matter the number of documents brought along, multiple visits are neces- 
sary to obtain the permit itself. Then, there is waiting for a public bus that, mysteriously, never arrives on schedule, meaning that either you or one of your friends will be late for a meeting in one of the kafanas where you also spend a night talking about waiting. Waiting for a delayed salary from one of the bars where a friend works. Another one is waiting for an Italian working visa that would enable him to get a seasonal job in an orchard or a vineyard where he would earn more than half of the Macedonian average yearly salary in a month or two.

On the other hand, everyday conversations and fieldwork interviews often revolved around waiting in a broader sense, especially in terms of Macedonian „European path" and overall economic and political progress. For example, one of my interlocutors in Kriva Palanka described his view of the situation:

Look, how to explain this now? My impression is that we are all waiting for something. Generally speaking, the whole society is apathetic. Everybody is waiting for something, the state is waiting as well, but at the same time, we are dealing with totally irrelevant problems. What do I mean by outside... In thirty years since we have been a country, we still have not succeeded in doing what we should be doing but are dealing with nonsense. Who is Macedonian, who is Albanian, who is in power, who is in opposition? Nobody is addressing real problems. The current government promised: „Lele, you will get $500 €$ of monthly salary, factories will start to open, there will be milk and honey for everyone." But of course, nothing happened. People need; we all need work. Everybody needs perspective in their lives. But this country, we are dealing with the name [of the country, cf. a.], we had to have the referendum, and then there are elections all the time. And for the last twenty years, they are telling us: "Wait for these elections to pass, then everything will be different." And when it seems that something will change, move forward, the government changes again, and the story starts from the beginning. And we are waiting all the time, waiting, and nobody takes any responsibility for the fact that nothing is moving anywhere. Our infrastructure is as it is. Bad.

Meanwhile, all other countries in the region are investing; look at Kosovo, Bulgaria,... Roads, railways, everything. Here, in Palanka, we have been building 60 kilometers of the railway for twenty years, more, for twentyfive, since 1995. It is a disgrace. And whenever there are elections, they are promising us that they will arrive by train at an election rally. But until today, not even one train arrived. But people are waiting. And how can they be trustful? How can they believe in institutions, the state? It is impossible.

For Ghassan Hage, waiting is an omnipresent phenomenon in life that it can almost be equated to social being. At the same time, that indicates that individuals and societies are engaged in life and have expectations from it (Hage 2009: 1). For Hage, there is one specific form of waiting that could also help us to understand the Macedonian case, namely the ,waiting out in which one is not waiting for something specific to come but rather for something undesirable or unwanted to end or go away (Hage 2009: 102). This, 
in turn, means that it „involves both a subjection to the elements or certain social conditions and at the same time a braving of these conditions, “ while it also functions as a „governmental tool that encourages a mode of restraint, self-control, and self-government in times of crisis“ (Hage 2009: 102). ,Waiting out" in the Macedonian context could therefore be understood as waiting for a period of "transition“ to come to an end so that the country and its citizens could start moving forward towards „normal lives.“ Hage points out that ,imaginary existential mobility" is one of the most critical factors that enable individuals to feel like their life is ,going somewhere and that they are not ,stuck' (Hage 2009: 102). The imaginary or concrete experience of existential mobility is, according to Harry Pettit and Wiebe Ruijtenberg, a necessary predisposition for an individual to give meaning to his or her life or to live a life worth living. Yearning for (existential) mobility often derives from growing dissatisfaction with present living conditions on one hand and the capitalist idea of the need for constant growth on the other. As their-mentioned authors point out, many ethnographic studies in the past few decades emphasize existential immobility or stuckness that prevents the hands' people from fulfilling their goals in personal terms (e.g. moving out of their parents' house, getting a permanent steady job, ...). Pettit and Ruijtenberg point out that reasons for this are often found in the discrepancy between ideals of capitalist system and reality in which the same standards and opportunities for everybody simply do not exist (Pettit and Ruijtenberg 2019: 730-731).

The feeling, widely present among my interlocutors, was that the last 30 years were marked with an unpredictable period of ,permanent crisis' that was often juxtaposed with the times of Yugoslav socialism that enabled them (or their parents) to live what they described as „normal lives.“ Topics related to the concept of „normal lives“ are relatively well researched in the area of former Yugoslavia (see, for example, Bartulović 2013; Greenberg 2011; Helms 2007; Jansen 2015), where everyday life in socialism serves as a reference point for how „normal life“ even today should look like. In his work about „normal lives“ in postsocialist Sarajevo, Stef Jansen points out that this notion somehow reveals more about what is wrong with the present situation and not as much about the actual state of affairs in the past (Jansen 2015). However, it is essential to point out that in Jansen's and the interviews I conducted, the common thread refers to loss of social security, jobs or opportunity to go on vacation, political instability, and worsening the countries' economic situation. As older interviewees pointed out, the main difference between experience and the present-day situation was that the Yugoslav system enabled or even encouraged at least some degree of existential mobility (or, for that matter, feeling of it), which is rarely the case today.

Conversations about the past often turned into yugonostalgic narrations about lost opportunities and glorification of life in socialism. And if Yugonostalgia could be, to some extent, quite easily dismissed as an idealized version of the past that has little in common with today's world, I think it is necessary to take a look at it from another point of view. The term itself was invented shortly after the dissolution of SFRY and initially pejoratively referred to individuals that expressed doubt about the disintegration of $\mathrm{Yu}$ goslavia or simply people that did not find a way in the new system and were therefore labeled as incompetent or even as „traitors of their homeland“ (Bošković 2013: 76). The initial researches about Yugonostalgia were consequently limited to studies about consumption practices before and after the fall of socialism. At the same time, potential dis- 
courses about the political or social component of Yugonstalgia were labeled as too emotional or biased and consequently recognized as irrelevant and useless (Hofman 2015: 150; see also Petrović 2016: 508).

Mitja Velikonja, on the other hand, defines nostalgia as a „complex, differentiated and changeable, emotionally full story that on personal or collective level celebrates romanticized lost times, peoples, things, feelings, smells, events, spaces, relationships, values, political and other systems, and at the same time - in stark contrast to the present bad situation - mourns their loss (2008: 25). And although Velikonja warns about inconsistencies or even contradictions in nostalgic narrations, he still recognizes them as a viewpoint into the everyday life of individuals that are „by celebrating the past expressing a critique of the present and in this way telling more about problems of today than advantages of former times“ (2008: 26). And while the nature of nostalgia among older interlocutors in Kriva Palanka was more similar to what Svetlana Boym calls „restorative nostalgia“ (see 2001: 41), younger generations that did not live in SFRY look at the matter in a more reflected way, mostly stressing out the possibilities of stable employment, less obvious ethnic divisions and the fact, that emigration more often just an option and not the only way towards „normal lives“ as this is the case today. One of my interviewees from the younger generation, Elizabeta, explains why she does not want to return to Macedonia from one of the Scandinavian countries where she lives for a few years now:

I do not want, for example, holidays to be a luxury. If you worked hard for the whole year, this should not be a luxury. But here, in Macedonia, it is a luxury for somebody to go on vacation. My parents went on vacation in 1997 for the last time, and they are still talking about it, although it has been more than twenty years since. And I do not want this here; life is only surviving, not living. And I do not want my kids to go through this; I do not want them to go through the same stuff I went through.

Here it shows that things such as yearly vacations, which my older interlocutors pointed out in various conversations as self-evident and something completely „normal,“ seem unattainable for members of younger generations that are, to achieve them, forced to move to capital Skopje or even outside the country, often to one of the Western European countries, United States or Australia.

This brings us to the second aspect of coping with everyday life in postsocialist Macedonia, hope. The latter is inseparably connected to imagining the future or, as Katy Fox puts it, „hope is not just thinking about the what will or should happen but an act that is taking place in a present-day situation to construct and give meaning to future“ (Fox in Bartulović 2013: 132). According to Mary Zournazi, Hope keeps the will to live going despite the despair one feels. Speaking of hope, one does not simply wish for a change or improvement in their living standard but imagines the world as it should be (Zournazi 2002:14-15). At the same time, hope generates the belief that it is worth living in unpredictable and uncertain times and denies the conviction that the situation is beyond repairable or that nothing more could be done (2002: 16). And although hopelessness is often more „attractive“ for a researcher because it is more widespread and easier to arti- 
culate, it is its opposite. This hope enables us to take a glimpse of the future (Gilbert et al. 2008: 11).

During my fieldwork interviews, I mainly focused on the future of European integration and how my interlocutors understand the term „Europe“ itself. I wanted to know how people see their future and what their hopes and aspirations are after the long and tiring process of transition during which accession to the European Union and a lesser extent, NATO, were presented as the final goal that will bring Macedonia on the way of prosperity and development. Although all of my interlocutors agreed with this vision and wanted to join European Union, some of them expressed doubt regarding the way the process is going. Often the change of the name of the country was seen as too big of a price to pay for joining the „European family.“ At the same time, the vicinity of the Bulgarian border and, therefore, good knowledge about Bulgarian experience in the E.U. triggered somewhat ambivalent feelings among inhabitants of Palanka. The Bulgarian state-issued Bulgarian passports to Macedonians (see Neofotistos 2014) enabled them to travel without visa restrictions and, therefore, gave them insight into their future in terms of possible mobility. At the same time, however, this also sparked a fear that emigration trends will grow even faster after accession to the E.U. The future of peripheral towns such as Kriva Palanka is far from bright. This was illustrated with the way how one of my interlocutors, a middle-aged woman Mila, described her view of Kyustendil, the first bigger Bulgarian city on the other side of the border:

When we join the European Union, nobody will stay in Macedonia. Everybody will move out, everybody-open doors. You know the story about Bulgarian passports, all of it is just out of economic reasons. And if we enter into European Union now, the borders will open, nobody will stay here, and the prices will go up. Everything is more expensive in Bulgaria. I do not know if you have been to Kyustendil? It is a town of zombies, dead people. It is just older people left. The buildings are dark; trees are growing through the windows; it looks like an atomic bomb was dropped there. There is no moving, no animals, no cats, no dogs: nothing, nothing. And there were 70.000 people in Kyustendil in the past; now there are under 30.000, I think. And that happened after Bulgaria joined the E.U. So there are no young people, just old ones that have nowhere to go. And people that stayed in public sector jobs, teachers, professors, customs officers, police officers. And they have lower salaries, almost two times lower, while the prices of goods are much higher.

Therefore, the biggest concern among the older generation was that young people would move out as soon as they get the chance to do so, which is, according to conversations that I had with them, not very far from the truth. However, all of the stress out that if there were at least minimum prospects on the horizon for them to set up a life that is, in Elizabeta's words, not just surviving, they would prefer to stay in Macedonia and create their futures here. European Union was, in this regard, seen mainly as an institution that will, besides new opportunities in terms of funding and development of projects, ensure tighter control over the consumption of public funds and corruption. During a hea- 
ted debate in the village of Trnovo, some 20 kilometers out of Kriva Palanka, Nikola presented his view of the situation in the following words:

New possibilities will open, especially in terms of tenders and availability of money from European funds. That is great, but I think that we got ourselves in a situation where no people would be able to take advantage of these opportunities. And this is because, for the last few decades, we did not invest in the development of some sectors that would cope with these challenges. Still, I think that accession to the E.U. is a positive thing. But, generally speaking, I think we need to build a functional system. What we have now is a dysfunctional system. And I know that things will not change by themselves /.../, but at least there will be some kind of mechanism that will control all this stupidity that our politicians do. We have to move away from these everyday fights and make a strategy for the future; we have not had this for the last thirty years in any sphere.

European Union, therefore, becomes a metaphor for a system that guarantees security, order, and work while at the same time opens space for "utopian hope“ in which Europe performs as a subject that ensures investitions and a structured system, through which it serves as a mechanism that enables individuals to move away from everyday reality that is marked by unemployment and uncertainty (Potkonjak and Škokić 2013: 88). In that context, European Union can be understood as a „hope-generating machine“ that derives its legitimacy out of the hope that people are constantly pinning on it (Nuijten in Jansen 2009: 59).

However, this does not mean that my interlocutors blindly believed that once they enter the European Union, their problems will disappear and were well aware of structural issues in the country and the E.U. itself. In the end, most hopes were still placed in the sphere of one's home, family, and close friends and mainly were not „directed" towards the broader political situation. It could be claimed that most people invented survival strategies during the last decades that enable them to maintain a certain level of social security in strictly personal terms and that guarantees them at least some level of autonomy. Here, generational differences play an important role and could be examined through three main sub-groups. The first group is pensioners, a generation born and spent most of its active life in SFRY. I conducted numerous interviews and unofficial talks with them, and they never embellished their words regarding political or economic topics. They, understandably, compared the situation today with the situation in socialism, which seemed superior to them in terms of housing, social security, personal and collective prospects, and the overall progress of the federation as a whole and Macedonia as one of the republics. They rarely expressed any hope or optimism that things will soon change for to better in Macedonia and mourned the fate of younger generations that do not have the same possibilities as they had. They are skeptical towards European Union and NATO, primarily due to their attitude towards Macedonia and Macedonian citizens during the last thirty years, which were, according to one of them, ,an agony that was prolonged and enabled because of the E.U.'s powerlessness and ignorance.“ 
Members of the second generation are those born in the decade before the dissolution of Yugoslavia and spent their adult life in independent Macedonia. Period of postsocialist transformation that marked the life of these people often meant a "frozen transition" to adulthood (see Kuhar and Reiter 2012), primarily since systems of social security were disappearing in front of their eyes. Housing, health, and school systems that were taken for granted one or two generations before were slowly falling apart, and one's prosperity and welfare were suddenly in the domain of individuals themselves and not the state anymore. Many people from this generation that I talked to honestly said they missed or did not even have an opportunity to move out of the country since they still hoped that things would turn in a good direction. This, however, does not mean that they are passive and hopeless "spectators“ of what is going on around them, but are instead the most active and politically conscious group that engages in NGO activities, participates in local politics, or different volunteer groups. One of them, Danijela, shared her view of the situation with me:

If I look at the whole situation at the end... Yes, we from the 80s, 90s and 2000s are maybe the lost generations. Meaning that we do not know what to do with ourselves, where to go; we should stay here or go somewhere abroad. I agree with those who say that many young people will move out after we enter the E.U. But I hope that we can learn something from the experience of other countries, how to reduce this period of emigration and how to lower the number of people that will move out. I hope that my children's generation will look at this period as an experience, a lesson and that they will have it better. My best years did not align with the best years of my country. And I hope this will change.

The last generation is the one born after Macedonian independence and is today in their mid-twenties. Most of them have decided or at least expressed an intention to move out of the country. They often spoke about Macedonia as a great country with many potentials where they would love to stay, but the overall political and economic situation deters them from doing so. This is why they often see emigration as the only way out of precarity and low-paid jobs for which they are overqualified and overeducated.

This, finally, poses a question that many of my interlocutors asked themselves during our conversations - who will stay in the country, and are they going to push it forward. Unfortunately, my feeling was that many of them, while actively trying to change things for the better on the local level, slowly started to give up since they realized that often there is little or no effect. The European Union is, together with all its downsides, therefore still perceived as and hoped to be the last straw that can ensure at least a certain level of desired prosperity. 


\section{References}

Bartulović, Alenka 2012 ,Neskočnost povojne ,rekonstrukcije؛: Sarajevo med upanjem in čakanjem.' Etnolog 22: 129-45.

Bošković, Aleksandar 2013 ,Yugonostalgia and Yugoslav Cultural Memory: Lexicon of Yu Mythology.' Slavic Review 72(1): 54-78.

Boym, Svetlana 2001 The Future of Nostalgia. New York, NY: Basic Books.

Burawoy, Michael and Katherine Verdery 1999 Uncertain Transition: Ethnographies of Change in the Postsocialist World. Lanham: Rowman \& Littlefield.

Danforth, Loring M. 1995 The Macedonian conflict: Ethnic nationalism in a transnational world. Princeton in New Jersey: Princeton University Press.

2010 ,Ancient Macedonia, Alexander the Great and the Star or Sun of Vergina: National symbols and the conflict between Greece and the Republic of Macedonia.' In: A Companion to Ancient Macedonia. Joseph Roisman in Ian Worthington, ed. Malden, Oxford, and Chichester: Wiley- Blackwell. Pg.: 572-599.

Daskalovski, Zhidas 2011 ,The Influence of E.U. Conditionality and Europeanization on the Consolidation of Macedonia.' In: 20 Years after the Collapse of Communism: Expectations, achievements, and disillusions of 1989. Nicolas Hayoz et. al., ed. Bern: Peter Lang. Pg.: 49-83.

Džankić, Jelena 2018 ,Structural Mechanisms of Power Reproduction in Bosnia and Herzegovina, Macedonia and Montenegro.' Southeastern Europe 42: 83-106.

Fidanovski, Kristijan 2018 ,What's in a Name? Possible Ways Forward in the Macedonian Name Dispute.' Slovo 31(1): 18-44

Filak, Manca 2016 ,Projekt Skopje 2014: Vpliv mestne prenove na identiteto mesta, socialni spomin in nacionalno zavest prebivalcev. 'Master thesis, Deaprtment of ethnology and cultural anthropology, Faculty of Arts, University of Ljubljana. 


\section{EthnoAnthropoZoom}

Gilbert, Andrew et. al. 2008 ,Reconsidering Postsocialism from the Margins of Europe: Hope, Time and Normalcy in Post-Yugoslav Societies' Anthropology News 48(9): $10-$ 11.

Greenberg, Jessica 2011 ,On the Road to Normal: Negotiating Agency and State Sovereignty in Postsocialist Serbia.' American Anthropologist 113(1): 88-100.

Hage, Ghassan 2009a ,Introduction. 'In: Waiting, Ghassan Hage, ed. Carlton: Melbourne University Press. Pg.: 1-12. 2009b 'Waiting Out the Crisis: On Stuckedness and Governmentality.' In: Waiting, Ghassan Hage, ed. Carlton: Melbourne University Press. Pg.: 97-106.

Helms, Elissa 2007 ,Politics is a Whore‘: Women, Morality, and Victimhood in Post-War BosniaHerzegovina.' In: The New Bosnian Mosaic: Identities, Memories and Moral Claims in a Post-War Society. Xavier Bougarel, Elissa Helms in Ger Duijzings eds., Hampshire: Ashgate. Pg.: 235-253.

Hofman, Ana 2015 ,Introduction to the Co-Edited Issue „Music, A Fect and Memory Politics in Post-Yugoslav Space".' Southeastern Europe 39: 145-164.

Jansen, Stef 2009 ,Hope and State in the Anthropology of Home: Preliminary Notes.' Ethnologia Europaea 39 (1): 54-60.

2015 Yearnings in the meantime: 'normal lives' and the state in a Sarajevo state complex. New York in Oxford: Berghahn Books.

Jezernik, Božidar 2002 ,Macedonians: Conspicuous by their absence. EthnoAntropoZoom 2: $1-20$.

Karakasidou, Anastasia N. 1997 Fields of Wheat, Hills of Blood: Passages to Nationhood in Greek Macedonia, 1870-1990. Chicago: University of Chicago Press.

Kuhar, Metka and Herwig Reiter 2012 ,Frozen Transitions? Young People in Former Yugoslavia.' In: 1989: Young People and Social Change after the Fall of the Berlin Wall, Carmen Leccardi et al. eds. Strasbourg: Council of Europe Publishing.

Malkovski Gjorgji, Jordan Mihajlovski and Cone Krstevski 1996 Kriva Palanka $i$ Krivopalanečko niz istorijata. Kriva Palanka: Sobranie na opština.

Monova, Miladina 2014 ,"We are all chasing after the euro": Labour, calculations, and ideas of well-being among tobacco growers in a Macedonian town. 'In: Social Prac- 


\section{EthnoAnthropoZoom}

tices and Local Configurations in the Balkans, Nedi Bardoshi et. al. eds. Tirana: UET Press. Pg.: 115-129.

2015a ,When the household meets the state: Ajvar cooking and householding in postsocialist Macedonia.' In: Oikos and market: explorations in self-sufficiency after socialism, Stephen Gudeman, ed. New York: Berghahn. Pg.: 77-100.

2015b ,We don't have work. We just grow a little tobacco.": household economy and ritual effervescence in a Macedonian town.', In: Economy and ritual: studies of postsocialist transformations, Stephen Gudeman, ed. New York: Berghahn. Pg.: 166-191.

Nedelkov, Ljupcho 2011 ,The Issue Of The Identity Of The Macedonian People: The Symbolic Code for a Personal and Collective Identity.' EthnoAnthropoZoom 9: 37-55.

Neofotistos, P. Vasiliki 2012 The risk of war: Everyday sociality in the Republic of Macedonia. Philadelphia: University of Pennsylvania Press.

2014 ,Bulgarian passports, Macedonian identity the invention of E.U. citizenship in the Republic of Macedonia.' EthnoAnthropoZoom 10: 37-53.

Petrović, Tanja 2016 ,Towards an Affective History of Yugoslavia.' Filozofija i društvo 27(3): 504-520.

Pettit, Harry in Wiebe Ruijtenberg 2019 ,Migration as Hope and Depression: Existential Im/Mobilities in and beyond Egypt.' Mobilities 14(5): 730-44.

Potkonjak, Sanja, in Tea Škokić 2013 ,»In the World of Iron and Steel«: On the Ethnography of Work, Unemployment and Hope.' Narodna Umjetnost 50 (1): 74-95.

Poulton, Hugh 2000 Who are the Macedonians? London: Hurst and Company.

Ramet, Sabrina P. 2017 ,Macedonia‘s Post-Yugoslav Reality: Corruption, Wiretapping, and Stolen Elections.' In: Building Democracy in the Yugoslav Successor States. Sabrina P. Ramet, Christine M. Hassenstab and Ola Listhaug, eds.. Cambridge: Cambridge University Press. Pg.: 287-320.

Risteski, Ljupčo and Armanda Kodra Hysa 2014 ,Strategies for Creating the Macedonian State and Nation and Rival Projects Between 1991 and 2012.' In: Strategies of symbolic Nation-building in southeastern Europe. Pal Kolsto, ed. Oslo: Ashgate. Pg.: 165200. 
Schwartz, Jonathan M.1996 Pieces of Mosaic: An Essay on the Making of Macedonia. Нøjberg: InterventionPress.

Tiessen, Ilka 1999 ,T'Ga za Jug - Waiting for Macedonia The Changing World of Young Female Engineers in the Republic of Macedonia.' PhD Disertation, London School of Economics, University of London.

Velikonja, Mitja 2008 Titostalgija: študija nostalgije po Josipu Brozu. Ljubljana: Mirovni inštitut.

Zournazi, Mary 2002 Hope: new philosophies for change. Annandale: Pluto Press Australia. 